
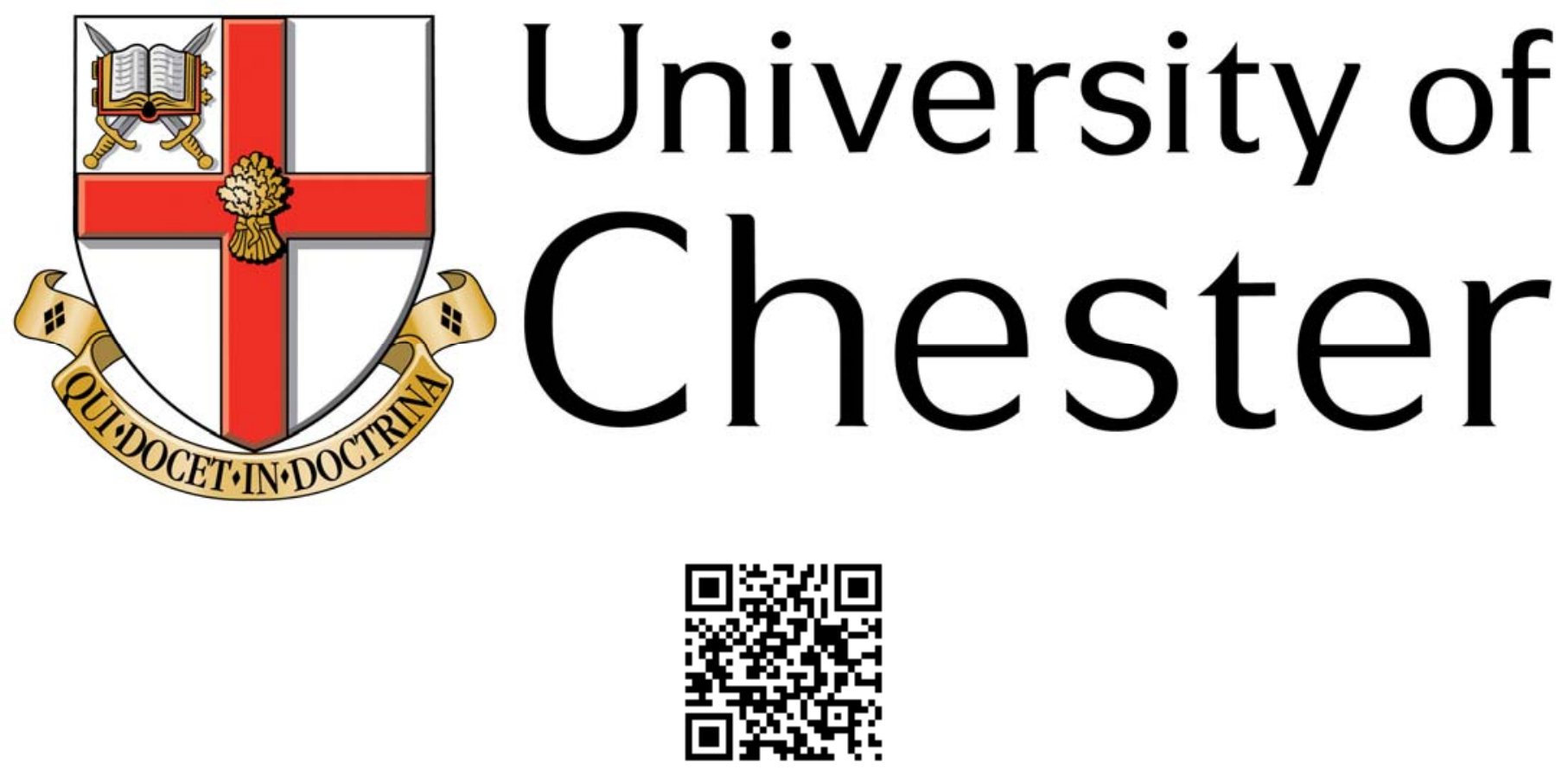

This work has been submitted to ChesterRep - the University of Chester's online research repository

\title{
http://chesterrep.openrepository.com
}

Author(s): Alana M Vincent

Title: Topos and Utopia: The place of art in the Revolution

Date: 2014

Originally published in: Jewish thought, Utopia and Revolution

Example citation: Vincent, A. M. (2014). Topos and Utopia: The place of art in the Revolution. In E. Namli, J. Svenungsson, \& A. M. Vincent (Eds.), Jewish thought, Utopia and Revolution (pp. 95-110). Amsterdam, Netherlands: Rodopi.

Version of item: Author's post-refereed pre-print

Available at: http://hdl.handle.net/10034/332064 


\title{
Seven
}

\section{TOPOS AND UTOPIA: THE PLACE OF ART IN THE REVOLUTION}

\begin{abstract}
Alana M. Vincent
The beginnings of the Jewish renaissance preceded the appearance of "The Jewish State" by several decades. [...] With the advent of Herzl, however, Zionism was no more a matter of domestic concern only. It was no longer an internal Jewish problem only, not a theme for discussion only at Zionist meetings, not a problem to heat the spirits of Jewish writers. The problem of Jewish exile now occupied a place on the agenda of international affairs.

Louis Lipsky, Introduction to Theodor Herzl's The Jewish State $(1988$, p. 14)

Representatives of all countries and nations! [...] Confess: Now, when Lenin sits in the Kremlin, there is no sliver of wood [for heating], smoke rises, the wife is angry- do you now have "national art?"

Marc Chagall, "On Jewish Art—Leaves from My Notebook"

(1922, p. 39)

As Mattias Martinson has written, Adorno begins his Negative Dialectics reaffirming the standard Marxist critique of philosophy: philosophy left to its own devices "is tragically incapable of materially actualizing the human freedom it constantly prates about in spiritual terms. Consequently, it cannot become a force of true political liberation or reconciliation" (p. 34). One may think the revolution, but so long as thinking is all one does, the project of revolution is truly utopian, in the original sense highlighted earlier in this volume by Michael Löwy: incapable of existing in any particular place. The revolution needs not only to be thought, but to be actualized; the transformation of utopias into actualized spaces of redemption is not a purely philosophical enterprise, but rather a task of worldmaking, in which every sphere of human activity is invested.

In taking this position, I am reading Hannah Arendt's The Human Condition slightly against the grain, though not, as I will briefly argue, in a manner which would be entirely unrecognizable to the author. Arendt presents that work as, in large part, a critique of Marxism's prioritization of the value of labor - and, indeed, she places labor at the very bottom of her hierarchy of human activity. She figures the laborer as animal laborans-not even including them in the genus homo-imprisoned "in the ever-recurring cycle of
\end{abstract}


the life process [...] being forever subject to the necessity of labor and consumption" (Arendt, 1998, p. 236). In Arendt's reading of Marx, labor is a ceaseless, inescapable cycle of production and consumption, in which no lasting gain is made - everything produced by labor is also consumed in order to feed the continuation of labor (ibid., p. 99). This cycle of ceaseless toil is, in Arendt's own words, "redeemed" by the intervention of "higher and more meaningful activities" (ibid., p. 5), performed by homo faber (who creates artifacts and stories which endure beyond the cycle of labor) and zoon politikon, who acts in the political and social spaces which Jon Wittrock discusses at some length in chapter 11.

Arendt is vocal in her defense of the value of political action, over and against any form of material production, and it is thus very easy for a reader to overlook the fact that in spite of her prioritization of the political, the separate spheres of human activity which she describes in The Human Condition are actually interdependent. This becomes especially clear in her development of the concept of natality, in which she looks to the promise of new life coming into the world to redeem action from the "irreversibility and unpredictability of the process started by acting" (ibid., p. 237). There is, however, nothing so linked to the ever-recurring cycle of the life process as the life process itself: the ever-recurring cycle of birth and survival and death, from which humanity seeks redemption through the construction of structures more enduring than a single life, be they physical - the work of homo faber - or political, located in the realm of action. But in the end, it is the basic reality of animal laborans, "the biological process of the human body, whose spontaneous growth, metabolism, and eventual decay are bound to the vital necessities produced and fed into the life process by labor" (ibid., p. 7), which Arendt's thought is not only unable to transcend, but to which she looks for the assurance of continuity which not only gives meaning to, but indeed makes possible, the various activities by means of which humans attempt to transcend it.

The interdependence between the various spheres of human activity also comes to the forefront in the section titled "The Permanence of the World and the Work of Art," where Arendt writes:

If the animal laborans needs the help of homo faber to ease his labor and remove his pain, and if mortals need his help to erect a home on earth, acting and speaking men need the help of homo faber in his highest capacity, that is, the help of the artist, of poets and historiographers, of monument-builders or writers, because without them the only product of their activity, the story they enact and tell, would not survive at all (ibid., p. 173).

My purpose in this chapter is to take seriously the place of activity beyond the political in the task of worldmaking that is necessitated by the revolutionary philosophies discussed elsewhere in this volume, and to examine how, in two concrete cases, the work of homo faber attempted to transform a utopian vision into a concrete topos. I will first, and at greater length, discuss the case 
of the early Bezalel School as an example of such a process of negotiation, highlighting the manner in which it both was driven by and supported the political project of the early Zionist movement, arguing that the rise of European nationalism and the concomitant emphasis on national spirit and folk culture expressed through the arts, coinciding as it did with debates over the integration of Jews into European society, led to an emphasis on Jewish material production as a locus of identity negotiation.

I will then, by way of a counterpoint, turn briefly to the work of Marc Chagall, who presided over the Vitebsk People's Art School in the years immediately following the Russian Revolution. Chagall is a considerably more complex political actor than was the founder of Bezalel, Boris Schatz; while at various points in his career he appeared to be aligned with the Bund, with Zionism, and points in between, if there is a consistency to his politics it is that he aligned with whatever party or movement appeared, to him, to offer him a platform from which to promote his vision of the future of art. In this regard, Chagall's work also functions as a locus of identity negotiation, but the identity in question belongs to the work itself, rather than the culture which produced it. Nevertheless, it is the work of Chagall, rather than Bezalel, which has become emblematic of "Jewish art," and this chapter will conclude by discussing the way in which Chagall mobilized both Revolutionary politics and the actual topos of the town of Vitebsk in order to fuel the production of symbolic utopias.

\section{Nationalism, Art, and the Invention of Aniconism}

Discussions about Jewish material production-visual images and the lack thereof-quite naturally tend to center around the Second Commandment and the variations in its interpretation which have arisen at different times and places. There exists a large body of material on these questions which I shall not review here, save to note two points.

First: that interpretations of the commandment have tended to be both more and less permissive than modern philosophers and art critics have understood-more, in the way that Talmud tractate Rosh Hashanah brings into question R. Gamaliel's diagram of the phases of the moon (a series of simple geometric symbols) (BT Rosh Hashana 24A), and less in that the Shulhan 'Arukh's exhaustive discussion of what sorts of images are permitted and what are prohibited serves to create rather more loopholes than it closes; this, I note in passing, having argued the point at length in previous papers (Vincent, 2013). It is interesting to note, however tangentially, that the story of the Shulhan 'Arukh is itself bound up in the emergence of ethno-linguistic nationalism, as the reception of Karo's commentary was instrumental in constructing a coherent Ashkenazi identity (Davis, 2002). 
Second: that the issue of graven images has always been intimately entwined with negotiations over the borderland between Jew and non-Jew; this is what I will argue, albeit in rather more constrained terms, in this paper. The Second Commandment has become an important explanatory mechanism for art historians in terms of accounting for the perceived absence of Jewish art - or minimizing the existence of Jewish art, whether (as in several cases chronicled by Olin, 2000) as a strategy to demonstrate Jewish cultural inferiority, or in order to emphasize the exceptional nature of a particular Jewish artist. And it has also become an important feature of contemporary discussions of art within Jewish Studies (see Raphael, 2009; and Rosen, 2009). In spite of this, the story of Jewish art in the modern era has, in fact, relatively little (though not nothing) to do with the Second Commandment save for the way that both art and the biblical prohibition against it function to mediate between Jewish and non-Jewish conceptions of identity and nationhood.

Kalman Bland has argued that medieval Jewish aesthetics tended towards the hyper-visual, and the idea of visual restriction governed by the Second Commandment entered into Jewish consciousness by way of Kant and Hegel, in the late eighteenth/early nineteenth century-the period in which European nationalism came to prominence, and the beginning of Jewish emancipation and widespread debate over the proper relationship between Jews and the nations in which they lived. The series of negotiations about the distinction between public and private space, what constitutes "culture" and the extent to which participation therein defined membership in society, all of these cultured the development of the self-perception of the European Jewish communities, as well as the way in which these communities were (and are) viewed by outsiders. These debates were especially tense in the regions of present-day Germany where Jewish emancipation was enforced following the Napoleonic conquest of 1811-1812; the fact that the integration of Jews into society was imposed by an invading force added an extra dose of resentment to an already tense relationship (Batnitzky, 2011, pp. 32-33). Attempts to allay this suspicion led Jewish leaders to emphasize Judaism's religious character, over and above any political or national content that might be inferred from the system of Jewish law (halakah) (ibid.). Kant's spiritualized reading of the Second Commandment, "perhaps the most sublime passage in the Jewish law," akin to Christian "presentation of the moral law," served to advance this project by overtly linking the practical, everyday halakah to a transcendent telos, thereby legitimizing halakah on spiritual, rather than political, grounds (qtd. in Bland, 2000, p. 15).

Indeed, in writing Jerusalem, or, On Religious Power and Judaism some seven years before the publication of the Critique of Pure Reason, Moses Mendelssohn attempted a very similar argument, removing halakah from the realm of the political and into the private domain (Batnitzky, 2011, pp. 22- 
23). While "Kant praised the work highly", he was evidently unconvinced by Mendelssohn's argument; his fondness for the Second Commandment is rather the exception to his general dismissal of Judaism as "a collection of mere statutory laws" rather than a proper religion (ibid., pp. 23-24). By contrast, Hegel saw in the Second Commandment proof positive of Judaism's inadequacy as a religion, noting that "the Jews and the Turks have not been able by art to represent their God, who does not even amount to such an abstraction of the Understanding, in the positive way that the Christians have" (qtd. in Bland, 2000, p. 15). However, Hegel's larger project left Jewish thinkers somewhat more room to maneuver; Bland asserts that

they used Hegelian categories and principles to prove Kant wrong when he declared Judaism lacking in true religion, ethical significance, and universal concern. When they finished their work, Judaism became fundamentally aniconic, pre-eminently spiritual, coterminous with ethics, and quintessentially universal (ibid., p. 16).

Margaret Olin has noted that the discipline of Art History also developed during the nineteenth century, largely in Germany and, at least in part, as an overtly nationalist undertaking, especially in the context of the 1871 unification of the various German states into a single country (2000, pp. 7-8). Olin traces three main narratives about Jewish art which developed over the course of the century: of "Jews as exotic purveyors of fantasy" (which Olin attributes to nineteenth century interpretations of biblical descriptions of the Temple and its furnishings, although Bland traces the trope of exotic and excessive Jewish visuality back to the medieval period), of Jews simply lacking a national art of their own (but being capable, and perhaps even interested in, imitating the art of other nations), and of Jews as actively hostile to images (ibid., p. 17). It is this last trope which she connects directly to the Second Commandment, as well as to Hegel and his intellectual heirs. The perpetuation of these tropes through the emerging academic discipline of Art History, as well as through Hegelian nationalism kept the ideas derived from the Second Commandment alive even among Jews who considered themselves thoroughly secular and assimilated. It is this combination of Hegel's theory of national spirit expressed through art with the last two tropes which had attained prominence by the time Boris Schatz sought permission from Theodor Herzl to found the Bezalel School in Palestine, in order to promote Jewish nationhood through the creation (ex nihilo) of a distinctive Jewish national art.

\section{The Bezalel School}

Theodor Herzl's The Jewish State offers up a vision of Jewish nationalism that is, if not consciously utopian, then certainly conscious of its potential to be 
perceived as utopian, with all the negative connotations of impracticality the term carries; the very first pages of Herzl's preface to the work are spent in an attempt to defend against such a perception. Herzl is, instead, at pains to emphasize the immediate practicality of his proposals, sketching a comprehensive plan for the building of his new society-or, rather, the transfer of European Jewish society to a new location, maintaining the class structures and habits of living to which the potential emigrants were accustomed, with the sole exception of the entrenched cultural anti-Semitism which, in Herzl's analysis, was the inevitable result of Jewish presence in Europe. Herzl argues that the process of emigration will offer great opportunity for class mobility, but-perhaps understandably, insofar as the pamphlet is, in part, a plea for investment and thus consciously courts the good will of the wealthy - only upwards mobility, as the poor and workingclass Jews who constituted the early waves of the settlement project benefitted from the boundless economic opportunities of the new country; Herzl is otherwise at pains to lay out plans for business owners and the upper classes to transfer their wealth and standard of living with as little risk of loss as possible:

We shall not leave our old home before the new one is prepared for us. Those only will depart who are sure thereby to improve their position; those who are now desperate will go first, after them the poor; next the prosperous, and, last of all, the wealthy. Those who go in advance will raise themselves to a higher grade, equal to those whose representatives will shortly follow. Thus the exodus will be at the same time an ascent of the class (Herzl, 1988, p. 82). Unlike Herzl, who grew up in a highly assimilated family, Boris Schatz came from a traditional Eastern European Jewish community; his father was a teacher at the local heder. He was born in Vorna, Lithuania, in 1867 and was educated at a yeshiva in Vilnius, before leaving to attend art school, first in Vilnius, then in Warsaw, and finally in Paris, where he was a student of Mark Antokolski (Bertz, 2003, pp. 248-249). Inka Bertz notes that

Antokolski, famous in Russia for his depiction of Ivan the Terrible and other patriotic gestures, still belonged to the generation of the Peredvishniki, the "Wanderers." In their concept, art had to be national art, expressing "the spirit of the people", and at the same time being comprehensible to "the people", since its task was to educate "the people" (ibid., p. 249).

The influence of Antokolski on Schatz is clear, both in terms of style - as both artists favored a naturalism that was increasingly out of step with the avantgarde mainstream - and in terms of philosophy; there is some evidence that Bezalel was Schatz's attempt to carry out a plan originated by his mentor (Manor, 2005, pp. 6-7). Schatz's first major experiment with creating a nationalist art was in Bulgaria, where he worked from 1895 to 1905; his experience there provided the basis for the later work of the Bezalel School (Bertz, 2003, p. 249). It is worthwhile to note that, while the Bezalel style 
promoted by Schatz drew on "ethnic types" as an expression of the "spirit of the people" (a concept borrowed from the Peredvishniki), Schatz's prior participation, as a Lithuanian Jew, in Bulgarian nationalist art indicates that he was not entirely committed to the idea of a specific, ethnically-based and genetically-transmitted, national genius. Rather, the adeptness with which he adopted a Bulgarian style, and the methods he used at Bezalel to encourage the development of a Jewish style, suggest that he viewed the national spirit as a combination of elements from the local environment and history of a community which, while specific to that community, remained accessible to anyone with the will to immerse themselves in them. There is, of course, a clear parallel between this cultural immersion and the process of religious conversion.

The Bezalel project developed within the wider context of the European folk revival (Manor, 2005, p. 6) -although even in this, Bezalel was somewhat behind the times for, as Bezalel was just beginning, the folk craft revival in Western Europe was already coming to its end: for example, the main publications of the British Arts \& Crafts movement, Craftsman and Handicraft, ceased publication in 1912 and 1916, respectively. At the same time, too, the Bezalel project also echoed the trope of European Jews as strangers in a strange land, divorced from their own cultural roots. In an early pamphlet promoting the school, Schatz lamented the inevitable assimilation of Jewish artists to their diasporic environments:

In order to develop his talents the Jewish artist must leave his Jewish environment and study in foreign countries, be influenced by a foreign spirit and work on foreign subjects. Thus, gradually, without noticing it, he removes himself from the Jewish people (qtd. in Manor, 2005, p. 15).

Schatz designed the Bezalel program with the aim of helping diaspora Jews to recover from this assimilation, or to avoid it all together, by immersing themselves in what he considered a pure Jewish ("Hebrew") culture, just as he had immersed himself in Bulgarian national culture during his time there.

Dalia Manor, the leading expert on the Bezalel School, describes at some length the steps that Schatz took to secure a proper environment in which to enculturate his students, from instruction in the Hebrew language, to the acquisition of a wide collection of local flora and fauna as well as archaeological artifacts and local crafts for students to study (Manor, 2005, pp. 25-28). The result of this program was a visual vocabulary

drawn from several sources: the past (Jewish symbols, the works of Jewish artists, archaeology, and the depiction of the Holy Places); the present (Zionist symbols and figures); and the environment of Eretz Israel (flora and fauna, ethnic prototypes, the pioneer life, and scenic and historical sites). An additional preoccupation was the revival of ancient elements such as the Hebrew letter and biblical topics (Cohen, 1994, p. 145). 
What emerged in the early twentieth century from the workshops of the Bezalel School was an art deliberately grounded in motifs from the craft traditions of the Levant region, rather than from the folk traditions of European Jewish communities, which were thought to be too derivative of non-Jewish cultures. That the folk traditions of European nations were increasingly considered to be central to the expression of national spirit rendered Jewish folk culture from the same areas suspicious, as Jewish craftswork very often bore a strong regional resemblance to non-Jewish works (for a lengthy discussion of Jewish visual borrowing in the medieval period, see Kogman-Appel, 2001). However, a recourse to non-European craft motifs did not grant the artists of Bezalel the political or cultural legitimacy which they sought within Europe. Rather than contesting their exclusion, as Jews, from participating in any European nationalist undertaking, this strategy served to confirm the basis of such an exclusion, which is not to suggest that Jews of the late nineteenth and early twentieth century were not very often ardent patriots of the country in which they resided - the historical record is clear that a large majority of Jews were deeply dedicated to their country-but rather that Herzl's analysis of anti-Semitism as embedded in European society was proven sadly correct; insofar as the logic of nationalism depends upon the creation of a group of outsiders against which the nation might define itself, Jews have tended to play the symbolic role of outsider far more often than they have been privileged insiders.

In acquiescing to the exclusion of Jews from European space, Bezalel surrendered any claim Jewish art might have made for significance as a Western tradition, relegating it instead to the Orient (a move which Zachary Braiterman (2012) has recently, and appropriately, termed "auto-Orientalism" (see also Braiterman, 2013)). Moreover, while within Europe the craft revival could be seen as a re-injection of national spirit into the bland and soulless work of academic art, non-Western craft was still treated as a lesser form of production, a fact of which Schatz himself was well aware (see Winter, 1975, p. 36). Manor reports that he published his very first paper on the issue of Jewish national art in 1888 (nearly twenty years before he began the Bezalel project) and, following his opening statements about the nature of art and beauty,

Schatz then suggests that the talent for painting and sculpture which was recently recognised among Jews was wasted on decorative religious objects. Although the makers excelled in their craft it was not highly appreciated and they were only titled 'craftsman' (Manor, 2005, p. 10).

The tacit acceptance of craft as a lesser form of production proved problematic to Bezalel in two respects. First, because initially the skilled craftsworkers employed at the school were primarily of non-European origins, it gave license to the already existing tendency of European Jews to Orientalize; rather than reclaiming these craft traditions as part of their own 
cultural heritage, and the craftsworkers (especially the Yemenite Jews employed as silver-workers) as equal inheritors, they instead exoticized the craft traditions, and transformed craft practitioners into a subaltern group, in need of the economic support that craftswork provided (although the craft workers at Bezalel were also notoriously - and controversially-underpaid; see Manor 18) but incapable of doing the hard work of translating craft motifs into expressive art forms; this task was reserved to the predominantly European students of fine art at the school (Manor, 2005, pp. 14, 17; for the problems this generated among the European students, see ibid., pp. 24-26).

Second, because Bezalel did continue to engage in a very deliberate mixing of fine art and craft production, it undermined the project's claim to artistic significance, as Nurit Shilo Cohen has made clear:

It is unclear which aspect of the institution was most important to Schatz - whether he wished to establish a Jewish academy of art, utilising the craft departments which furnished the local population with an income as an excuse for obtaining support and financing, or whether he really wished to develop a mass industry of popular crafts alongside an academy of art. It is important to note that there was no clear-cut separation between the two parts of the institution. The art students were obliged to study crafts while the craftsmen studied drawing in night classes. Schatz believed that it was impossible to be an artist without being an artisan, and that artisans should learn the art of painting (Cohen, 1994, p. 142).

While the two forms of production and their practitioners existed side-by-side, the mutual enrichment that Cohen hints at here, and that I agree was Schatz's aim, never really emerged; instead, the products of the early Bezalel School were received as almost entirely commercial in nature, as craft of high technical proficiency but limited aesthetic value: " fancy articles for luxurious tourists' whose aesthetic value 'is not of this time" and which never quite acquired the veneer of artistic respectability which it desperately sought (Manor, 2005, pp. 20-23).

The early Bezalel project's strategy was by no means a resounding success, in large part because neither its founders nor its audience could ever completely divorce themselves from the aesthetic heritage of Europe. This was attested to in part by the school's closure in 1929, and again by the critical reception that greeted the New Bezalel School when it opened in 1935, which tended to echo critiques of the original Bezalel School. W. A. Stewart, writing in 1944, reported that

The Yemenite Jews have always produced fine silver and gold filigree, but some of the younger men have received training at the new Bezalel school of applied arts and are now turning out fine table silverware of simple and good design, for which there is always a limited number of buyers. Their jewellery has been modernized also, and is more acceptable to the European section of the public than the over-ornate and weak ornaments of the Yemenite 
tradition. On the whole it can be said that silver-work and jewellery are of fine craftsmanship with designs tending to follow the simple forms of modern European design (1944, pp. 267-268).

Likewise, William Schack, in 1966, wrote that "Aside from western art, in which, as has been noted, the historic gaps are large and hard to fill (we shall see whether the Israel Museum will be able to snare Old Masters permanently as it did for an opening loan exhibition), the Israeli museums have a good sampling of eastern art in some limited areas" (1966, p. 382). The local and particular continue to be measured against their relation to the (European) universal, the former valuable only insofar as they proved access to, or serve to in some way illuminate, the latter; the "many notable objects" in Bezalel's "large collection of Near Eastern, and especially Persian, art ranging over a thousand years" (which had, by the time Shack wrote, been incorporated into the newly-opened Israel Museum) held little value in comparison to the Old Masters which it lacked (ibid.). This is a sharp departure from the motivation behind the original Bezalel collection, which originated in 1906, when Boris Schatz began to gather objects, including "samples of Jewish ritual objects, works by Jewish artists, and local archaeological items" in order for Bezalel students to study and base designs on them; the school also hosted a museum of natural history, featuring flora and fauna from the region, developed for a similar purpose: "The singularity of Bezalel [...] lies in its motivation: the attempt to create a total environment, a 'Hebrew' environment influencing everyone and everything in it" (Cohen, 1994, p. 140).

The failure of the original Bezalel School was, in part, and in spite of the eventual success of the new incarnation of the project which opened in 1935, a failure of this vision: it was, from the beginning, precisely not a total "Hebrew" environment, but rather a response to the European environment, and no amount of effort on the part of Schatz, the other staff, or the students of the school could sever those roots. In this regard, the project of creating art which reflected the national spirit may be deemed a backhanded sort of success: the nation-building project as a whole has tended to re-inscribe the problematic aspects of European culture from which it has struggled, and proven unable, to free itself. This was noted as early as 1966, when Schack chronicled the emerging role of the country's museums in promoting and maintaining a European cultural outlook: "What the Israeli leaders fear, now that the emigrants from the Oriental countries constitute a majority of the population, is levanization" (1966, p. 378).

The deliberate attempt at constructing a Jewish national art at the Bezalel School both attempted to assert Judaism's equal standing with the national cultures of Europe and acknowledged the degree to which Judaism was excluded from European culture; both attempted to elevate Jewish cultural production to the same level as that of European nations, and also implicitly accepted European narratives concerning Judaism's lack of a truly native 
artistic culture. The complex picture which emerges from the nineteenth and early twentieth centuries, and with which contemporary scholars still contend, is one of Judaism as a cultural system that, in its scripture, its philosophy, its history, and its art, is both embedded in and also very much outside of the culture of Christian Europe which is still, in spite of the best efforts of scholars of and from other cultures, the basis for ideas of the universal. In the end, the Bezalel project proved unable to extricate itself from the system of cultural hierarchy it was meant to provide an alternative to. It was from first principles engaged in upholding precisely the notions of creativity, of belonging, and of cultural relevance which taken together served to enforce Jewish alterity.

\section{The Vitebsk School}

In contrast to Bezalel's failed project of creating a Hebrew national art totally divorced from European influence stands the work of what may be loosely termed the Vitebsk School-although Aleksandra Shatskikh is swift to point out that the notion of a particular Vitebsk School "is without legitimate standing in the history of Russian art" (2007, p. 11). By this, Shatskikh does not mean to suggest that either Yehuda Pen's School of Drawing and Painting (which operated from 1891 until 1918), or the Vitebsk People's Art School, which was founded, at the invitation of Anatoly Lunacharsky (Harshav, 2004, p. 242), under the guidance of Marc Chagall during his time as Commissar of Arts in post-Revolutionary Vitebsk, are not acknowledged as legitimate institutions, but rather that there is no particular overarching style associated with Vitebsk - at least, prior to the advent of the Suprematist-influenced Unovis movement, led by Kazimir Malevich, which very quickly eclipsed Chagall's vision at the People's Art School (Shatskikh, 2007, p. 146).

In spite of his 7 November 1918 speech celebrating the Revolution as "the collapse of the Academies of the 'Professors' and the restoration of the power of Leftist Art in Russia” (Chagall, 1918, pp. 28-29), Chagall's school was organized in the classical European fashion, with artists accepting students into their individual studios; while it did include studios dedicated to decorative arts, such as that presided over by Ksana Boguslavskaya (Shatskikh, 2007, p. 35), there was no overarching curriculum that forced students to move back and forth between disciplines, as existed in the Bezalel School. Nor was there an attempt to create a totalized academic environment in which a particular sort of artistic output might be encouraged; rather, the work of the school was itself part of the Revolutionary project of creating a totalized civic environment in which the ideals of the 1917 Revolution might be fully realized. To this end, much of the school's early output involved decorating the city of Vitebsk for various public celebrations. While the school existed in the broad milieu of the post-Revolution Jewish cultural 
renaissance described by Kenneth B. Moss (2009), and was certainly not inimical to a Bundist cultural vision, to the extent that the school attempted to use art to promote a national identity, that identity was Russian (and Revolutionary); the number of Jewish artists in the school's ranks was a result of the ethnic makeup of the area, and served as confirmation of the ability of the new world order to absorb ethnic differences.

This is not without its historical irony, as the work of Chagall rather than any artist associated with Bezalel, is now the most readily recognizable Jewish art of the twentieth century. His success is due, in no small part, to his ability to assimilate the concerns of the European avant-garde (Fauvism, Cubism, Surrealism) into his own, clearly identifiable, artistic style, and that style mattered more, to the art-purchasing public, than the clearly Jewish subject matter-or, at least, the style helped to render the subject matter palatable. But the question before us in this chapter is not the question of what makes Jewish art, but rather how art is mobilized in service of Revolutionary and Utopian visions; in this regard, Chagall's work in Vitebsk in the years 1918-1920 - and later on in Moscow, from 1920-1922 - is difficult to assess, as Chagall himself appears ambivalent towards the project of the proletarian revolution, and perhaps towards revolution in general. Or, rather, his understanding of that project is so much in contrast with other visions of Revolutionary Art, such as Unovis, that it hardly seems related.

Chagall was not particularly interested in the idea that animated so many movements of Revolutionary Art-Futurism, Suprematism, Proletkult, etc. - "that concrete reality could be changed by art and hence by the artistic will" (Bird, 1987, p. 223). While he paid lip service to this concept, he never appears to truly embrace the position that the purpose of art is to promote the Revolution. Rather, he saw in the Revolution an opportunity for greater artistic freedom. These two ideas are not necessarily mutually exclusive, of course - as Chagall's tenure as the Commissar of Arts demonstrates, for at least some time his vision was sufficiently in harmony with the post-October government for each to perceive the other as a source of support.

The eventual division and collapse of relationship between Chagall and the Revolutionary government can be understood best as follows: for Chagall, Art was Revolution; for the Revolutionaries, the Revolution itself was the highest form of art. Hints of this division could be seen even as early as 7 November 1918, in Chagall's speech "Art on the Anniversary of October," in which he both aligns art with Revolution and at the same time insists on its autonomy:

Art lived and will continue to live by its own laws. But in its depths, it undergoes the same stages experienced by all humanity, advancing toward the most revolutionary achievements. And if it is true that only now, when humanity has taken the road of the ultimate Revolution, can we speak of 
Humanity with a capital $\mathrm{H}$, even more so, can Art be written with a capital A only if it is revolutionary in its essence (Chagall, 1918, pp. 28-29).

Statements such as this one sound appropriately revolutionary, but Chagall consistently prioritizes the autonomy of art, which "lived and will continue to live by its own laws" over and against the need for art to be "written with a capital A only if it is revolutionary in its essence."

What in 1918 was merely hinted at comes fully to the forefront in Chagall's 1919 essay, "The Revolution in Art":

When we speak of Proletarian Art, we are usually thinking of its important and undisputed ideas and tasks: who would agree to remove its "content"? But here we encounter the "subject matter." Do you think that if the "subject matter" represents the life of a worker or of a peasant, rather than insects, and in an uninspired way, it is Proletarian Art?

No, I will never be convinced that Antoine Watteau, the painter of elegant parties and the refined reformer of the plastic art of his century, is inferior to Gustav Courbet solely because the latter represented workers and peasants on his canvases. But the art of today, like the art of tomorrow, doesn't want any "content," and only reluctantly does it accept compromises and concessions in this realm. So we must be wary about defining Proletarian Art. Above all, let us be very careful not to define it by its ideological content, in the usual sense of that word. It is precisely this aspect that we must banish definitively (Chagall, 1919, p. 31).

Chagall's eventual definition, in this same essay, of "Proletarian Art" as art which is made by proletarian painters hardly seems convincing following this defense of Watteau's decidedly bourgeois Rococo style - and it is Watteau's style, rather than his content, which most differentiates him from Courbet, the latter of whom produced his share of canvases on themes more classically aristocratic than "workers and peasants." And this is the core of the issue: Chagall is willing to include Watteau in his definition of Proletarian Art because he is a good artist; he is "the refined reformer of the plastic art of his century," much in the same way that the drunken and ineffective Noah was righteous in his generation (Rashi on Genesis 6:9): while neither may appear particularly admirable when judged by the standards of subsequent generations, nevertheless their efforts within their own context are worthy of praise. Watteau contributed to what, in Chagall's mind, is the true struggle of the Proletariat: the advancement of the work of Art - not, it must be noted, "the inaccessible "Art for Art's sake" (Chagall, 1919, p. 30) that Chagall accused even other Revolutionary artists of pursuing; not the abstract geometric formalism which the Futurists and their successors envisioned as the new Proletarian style (though there is some question as to how accessible the Proletariat found it (Bird, 1987, p. 224)), which is itself a continuation of the trends of the previous century's academic art, but rather an art which turns the progress of formalism on its head, placing the resources of the entire 
history of art (and not merely the most recent era) in the hands of the Proletarian painter, of which Chagall himself was the ideal type.

Chagall's attempt to redefine Revolutionary Art away from either formal or content-based concerns (that is to say, from being either geometric abstraction or pictures of workers) was essentially a self-protective move; he was attempting to develop a definition that permitted his own images, with their idiosyncratic style that owed more to the French avant-garde and Russian folk art than to the influence of Futurism, and their deeply personal (in fact, often autobiographical) presentation of local and Jewish subject matter, to not only inhabit Revolutionary space, but to define it. In this regard - in this regard and no other-Chagall's project was as much a failure as the Bezalel School's; his students at the Vitebsk People's Art School eventually preferred the approach of Malevich, and in 1920 Chagall departed Vitebsk, first for a brief tenure as a designer in the Moscow Yiddish Chamber Theatre, and then, in 1923, back to Paris (Shatskikh, 2007, pp. 146-147).

\section{Art as Topos and Utopia}

Chagall's lack of success as a state artist in post-Revolutionary Russia should not be misread as a failure of his vision of Revolutionary Art. To the contrary, the body of work he produced over the course of his career achieved precisely the aims that he set out in his writings of 1918-1919: his style lived by its own laws, assimilating to itself anything which progressed Chagall's vision, and ignoring a great deal of influence which Chagall considered incompatible. And, as he predicted in his 1919 essay, "The voice of the masses will always recognise the truth" (Chagall, 1919, p. 31)-his work, far more than that of the colleagues whom he left behind in what had, by then, become the USSR, continues to have a large audience outside of the academic elite.

I would suggest that Chagall's success comes, in part, from his use of space, in contrast both to the Bezalel experiment and the Revolutionary avantgarde to which his contemporaries Malevich and El Lissitzky belonged. The latter was very literally Utopian; its tendency towards geometrical abstraction prevented it from forming any connection to an actual place, or the people in it. Suprematism may have sounded very convincing as a manifesto, but in practice it was too much an insiders' game to make much connection with the Proletariat it purported to serve. By contrast, the Bezalel project was very nearly pure topos, attempting to rescue Jews from oppression in Europe by creating a Levantine cultural imaginary; it floundered in its inability to divorce itself from the former completely enough to fully inhabit the latter, and failed to create the Utopia it sought in real space. Chagall played in the space between topos and Utopia, anchoring his fantastic, dream-like landscapes - even those which purport to be images of Jerusalem, the space which so captivated the Bezalel artists - with the image of the skyline of 
Vitebsk (see also Vincent, 2010, pp. 155-156). Certainly, this is an idealized, nostalgic Vitebsk, cleansed of all the disappointments that caused Chagall to leave it, not once, but twice; it is transformed in art from topos to Utopiaand only in art is such a transformation possible. 
